\title{
No net loss of biodiversity or paper offsets? A critical review of the French no net loss policy
}

\author{
Fabien Quétier $^{\mathrm{a}, \mathrm{b}, *}$, Baptiste Regnery ${ }^{\mathrm{c}}$, Harold Levrel ${ }^{\mathrm{d}}$
}

\author{
a Biotope, 22 Boulevard Maréchal Foch, BP 58, F-34140 Méze, France \\ b Laboratoire d'Ecologie Alpine, UMR 5553 du CNRS, Université Joseph Fourier, BP 53, F-38041 Grenoble \\ Cedex 09, France \\ ${ }^{c}$ Muséum National d'Histoire Naturelle, UMR CNRS-MNHN-PARIS VI., 55 Rue Buffon, F-75005 Paris, France \\ d IFREMER, UMR AMURE, Marine Economics Unit, BP70, F-29280 Plouzané, France \\ *: Corresponding author : Fabien Quétier, Tel.: +33 621512666 ; email address : fquetier@biotope.fr
}

\begin{abstract}
:
French regulations concerning the mitigation of development impacts have been progressively strengthened with offsets now required for impacts on forests, wetlands, and protected species, among others. In 2012, following a national consultative process called Grenelle de l'Environnement, legal requirements in terms of monitoring and effective implementation of measures aimed at avoiding, reducing and offsetting impacts were strengthened. This has created strong "demand" for offsets.
\end{abstract}

The workability of these new requirements has come under scrutiny, not least because of their strong legal and financial implications for developers. In this context, official government guidance on implementing the mitigation hierarchy was published in 2012. Under this guidance, the aim of the mitigation hierarchy is to achieve no net loss (NNL) of biodiversity, and preferably a net gain for currently threatened biodiversity and ecosystems. We discuss what NNL means in this context, and highlight some of the technical and governance issues raised by the French approach to NNL.

Our analysis shows that the French guidance, in spite of its laudable ambition, does not address the institutional arrangements and science base needed to reach the policy's objective of NNL. The burden of designing and building adequate institutional arrangements is shifted down to local and regional permitting authorities, and even developers themselves. Consequently, and in spite of the increasing demand for offsets, the result is a highly variable and often ineffective project by project approach to offset supply, with minimal commitments. Unless the institutional and scientific challenges are tackled, the likely outcome will be an expansion of "paper offsets".

\section{Highlights}

Offsetting development impacts could help achieve no net loss of biodiversity. France recently geared its legislation on offsetting towards no net loss. New guidance promises improved offset design and implementation. Institutional arrangements for delivering offsets are either poor or lacking. Appropriate institutional arrangements are necessary to avoid paper offsets.

Keywords: No net loss ; Biodiversity offsets ; Ecological compensation ; EU Habitats Directive ; European biodiversity strategy ; Environmental impact assessmen ; Ecological equivalencies ; France 


\section{Introduction}

The headline objective of the EU's most recent Biodiversity Strategy (European Commission 2011 ) is to halt the loss of biodiversity and the degradation of ecosystem services by 2020 , and to restore them as far as feasible. In this context, the European Commission announced an initiative under Target 2 of the Biodiversity Strategy 'to ensure there is no net loss of ecosystems and their services (e.g. through compensation or offsetting schemes)' (EC 2011). Determining what no net loss (henceforth NNL) actually means and how offsetting can contribute to it will be critical to designing appropriate policy instruments for reaching the strategy's goals.

Offsets are defined as the last step in a sequence of avoiding, reducing and offsetting or repairing impacts on the environment that is known as the mitigation hierarchy. This hierarchy is central in much of the environmental legislation of the European Union (Jiricka \& Pröbstl 2009, McGillivray 2012). In France, the mitigation hierarchy was incorporated into environmental law in 1976 but offsets remained, for the most part, ignored or ill-applied until EU Directives were progressively transposed into French legislation from 2007 onwards. This has drawn the attention of both developers and public authorities to previously neglected "ecological compensation" requirements. Following various changes in the corresponding legislation, the French government published guidance on the mitigation hierarchy which explicitly outlines NNL as its goal (MEDDE 2012a and 2013). Valuable lessons could be learned from this process.

Experience shows that effective implementation and enforcement of offsets is at least as important for achieving NNL as appropriate offset design, if not more so (Hough \& Robertson 2009, Morandeau \& Vilaysack 2012, Bull et al. 2013). Our assumption is that if no ambitious institutional arrangements are adopted in parallel with the new requirements for offsetting spelled out under the French NNL policy, this could lead to "paper offsets" - akin to "paper parks" where protected areas are not actually enforced on the ground, but with added twist of areas being protected as offsets that were not actually threatened.

To address this question, we describe France's most recent environmental policy developments around the NNL principle. Following a review of official policy documents, we critically discuss the coherence between these legal developments and the institutional and organisational needs for effective implementation and enforcement. Our analysis identifies some of the missing design elements for an effective NNL policy based on offsets, which is applicable to France as well as other jurisdictions.

\section{The path to NNL in France}

\section{The slow transposition of EU directives into French law (1992 - 2010)}

As outlined above, the transposition of European directives has been a major driver in the recent reinforcement of the mitigation hierarchy in France. The EU directive 92/43/EC of May $21^{\text {st }} 1992$ (known as the 'Habitats Directive') was a major step for nature conservation in Europe (Ledoux et al. 2000). Through its articles 12 and 16, the Directive conditions the possibility of impacting protected species of plants and animals (those listed in Annex IV of the Directive) to a set of requirements: that the impacting project be justified by reasons of overriding public interest (these reasons are listed in article 16[1]), that no alternatives exist to the project, and that allowing the impacts does not preclude the reaching or maintaining a favourable conservation status of the impacted species (European Commission 2007a). 
European Commission (2007a) guidance states that "the net result of a derogation should be neutral or positive for a species" (page 62).

It follows that maintaining a favourable conservation status of the impacted species fits the definition of NNL, and offsets are in fact suggested by the guidance as a way of achieving NNL: "even though compensation measures are not mentioned in Article 16, and are as such not obligatory" they may be envisaged under Article 12(1)(d) "in case of deterioration or destruction of breeding sites and resting places" and they "would have to (i) offset the negative impact of the activity under the specific circumstances (at population level), (ii) have a good chance of success and be based on best practice, (iii) guarantee a species' prospects of achieving [favourable conservation status], and (iv) be effective before or at the latest when deterioration or destruction of a breeding site or resting place starts to take place" (page 63).

In France, article 16 of the Habitats Directive was only transposed through article 86 of Law 2006-11 of January 5th 2006 and, until 2007, no specific procedure existed in France for legally allowing impacts on species of 'community interest', and their habitats (except for scientific purposes). Impacts on biodiversity were only considered through generic EIA procedures. The introduction of derogations into French law was a political response to wolves (Canis Lupus, L.), a protected species, preying on domestic flocks in the French Alps (Conseil Constitutionnel 2012). The subsequent decree of February $19^{\text {th }} 2007$ set up a procedure to grant derogations to the strict protection of species whereby, if necessary, mitigation and offset measures must be taken in favour of the impacted species to ensure there is no decrease in its conservation status. Many species that are protected under French law are not listed in Annex IV of the Directive. For some of these, only individuals are protected, not their habitat. A national consultative body on nature protection (Conseil National de la Protection de la Nature) gives an opinion on the requests for derogations, and in practice it acts as an independent third party regulator in the granting process. As showed in Figure 1, the 2007 Decree has led to a steady increase in the number of derogation procedures under article 16 of the Habitats Directive.

The Habitats Directive also conditions consent for impacts on the Natura 2000 network to a two-step process described in its articles 6(3) and 6(4): on the basis of an appropriate assessment of the implications of a plan or project for reaching the conservation objectives of a Natura 2000 site, a project with adverse effects on the integrity of the site can be allowed for overriding reasons of public interest, if there are no alternatives to the project, and if compensatory measures are adopted that ensure that the overall coherence of the Natura 2000 network is protected (European Commission 2007b). On June $2^{\text {nd }} 2008$, the European Commission took France to court for not complying with the requirements of articles 6(3) and 6(4) of the Directive (case C-241/08). In response, France reformed its legislation through law 2008-757 of August $1^{\text {st }} 2008$.

In 2009, the River Basin Management Plans established under the Water Framework Directive (2000/60/EC) and known as Schémas Directeur d'Aménagement et de Gestion des Eaux (SDAGE) were reviewed and updated. Several of these SDAGE now require offsetting for residual impacts on wetlands. For example, the SDAGE of the Loire river basin requires the re-creation or restoration, in the same catchment area, of a wetland with equivalent function and biodiversity to the wetlands destroyed. If these conditions cannot be met (i.e. offsets are over $25 \mathrm{~km}$ away from the impacted wetland or if the catchment area is greater than $500 \mathrm{~km}^{2}$, and/or if equivalence for functions and biodiversity cannot be found) then a 2 to 1 area ratio will be applied (action 8B-2 of SDAGE Loire-Bretagne - Secrétariat technique 2010). Such area ratios have been put forward in most river basins. The legal definition of a 
wetland in France (established through Ministerial Order DEVO0813942A of 2008) is very broad: any hydromorphic soil is considered a wetland. This includes most recently drained agricultural soils. As a result, considerable offsetting requirements have been imposed on development in lowlands and river floodplains. Area-based offset multipliers are also used in the permitting process for deforestation, as detailed in MAAF (2013).

\section{The Grenelle de l'Environnement and the reform of EIA and SEA (2007-2013)}

In May 2007, a national consultative process called "Grenelle de l'Environnement" was launched to update French environmental policies and legislation. Through law 2010-788 of July $12^{\text {th }} 2010$, it led, among other thing, to two important sets of reforms concerning the mitigation of development impacts on biodiversity. First, planning instruments aimed at incorporating landscape-level connectivity criteria into land-use and infrastructure planning (known as trames vertes et bleues, which can be translated as 'green and blue veins' or 'corridors') were set-up. Second, the requirements for assessing impacts of projects, plans and programs were reformed together with enforcement capabilities. We describe below the most important changes introduced through the EIA and SEA reforms:

- Scope: The scope of EIA was expanded to cover every project likely to have a significant effects on the environment or human health, with this likelihood being examined on a caseby-case basis instead of being based on a budget threshold of 1.9 M€. The reform established a list of projects (in type, size, and location) for which EIA is always required as well as a list of exemptions (available in article R.122-2 of the French Environmental Code). Development authorized following the SEA of a planning document can be exempted from the EIA requirement.

- Cumulative impacts: The requirement to assess the cumulative impact of the project with those of all other known projects has been strengthened. Environmental authorities must provide a list of all "known projects". Project proponents can now provide a preliminary assessment to request official guidance on the expected content and level of detail of the final EIA document required to seek consent for their project.

- Legally binding mitigation measures: Permits granted on the basis of an EIA must now include the mitigation measures presented in the EIA document, including avoidance, reduction and compensation or offset measures (with their associated cost). This makes mitigation measures legally binding.

- Monitoring: The permit must now also include a monitoring plan regarding the adequate implementation and on-the-ground effects of mitigation measures. Monitoring results must be communicated to the environmental authorities.

- Compliance: Through Ordinance 2012-34 of January $11^{\text {th }}$ 2012, mitigation measures must be controlled by environmental authorities and a system of administrative penalties applies in the case of failure to implement mitigation measures detailed in the permit.

The reform of Environmental Impact Assessment (EIA) procedures came into force on June $1^{\text {st }} 2012$ and generalized developers' liabilities regarding measures aimed at mitigating their environmental impacts. Similar changes were introduced concerning SEA through Decrees 2012-616 and 2012-995 which have been applicable to planning documents since early 2013. These reforms have generated considerable uncertainty for developers and public authorities, especially regarding the nature and cost of offset measures.

Offsets are legally defined as measures that 'aim to offset the significant negative effects, direct or indirect, of the project that could not be avoided or sufficiently reduced. They are implemented in priority on the damaged site or in proximity to it, so as to ensure its 
functionality through time. They must ensure that the environmental quality of habitats is globally maintained or, if possible, enhanced' (article R.122-14-I of the French Environmental Code). In order to clarify how this is to be interpreted the French government formulated a guidance document that details how the mitigation hierarchy is to be applied. We detail below how offsets are dealt with in this guidance.

Biodiversity offsets as defined in the 2012 French government guidance

The 2012 guidance states that "implementation of the mitigation hierarchy is intended to conserve the overall environmental quality of habitats, and if possible to achieve a net gain, in particular for degraded habitats, taking into account their sensitivity and general goals for achieving good conservation status of these habitats" (MEDDE 2012a, our translation). The notion of environmental quality, and its assessment as "good" or "degraded", is defined in reference to specific sectorial policies: "favourable conservation status of natural habitats and wild species of fauna and flora, good ecological and chemical status of water bodies, good ecological status of marine waters, good functionalities of ecological connexions...)" (MEDDE 2012a, our translation).

It follows that NNL is the stated policy goal, and offsets a key mechanisms for achieving it. The French government sought to clarify some of the key issues regarding offsets by stating in its guidance (our translation with key words highlighted in bold) that:

1. Offset measures must restore environmental quality of the impacted biodiversity to a level at least equivalent to its initial level and if possible a better state, in particular for degraded habitats, because of their sensitivity and because of broader objectives regarding their good ecological status. It is the project proponent's responsibility to fit into a net gain approach to offsetting impacts. The concept of environmental quality and how it is measured will depend on sectorial policies and regulations: conservation status of species and habitats, good ecological and chemical status of water bodies, etc.).

2. Offsets measures must be feasible and project proponents must assess the technical feasibility of reaching the measures' ecological goals, estimate the associated costs for the planned duration of the measures, ensure that the measures can in fact be implemented on the planned site, define the institutional set-up, and suggest a detailed time-line.

3. Offset measures must be appropriately located, in functional proximity to the damaged site, and they must contribute to maintaining or improving the damaged biodiversity at the appropriate spatial scale.

4. Offset measures must be timely and no irreversible damage must be done before offset measures are in place. Exceptions can be made when it is demonstrated that they do not compromise the efficacy of the offset measures.

5. Offset measures must be performance-based, with stated and measurable ecological goals, associated with protocols for monitoring their effectiveness (was action taken?) and efficacy (did it work?).

6. Offset measures must be additional to existing or planned public policy targets for biodiversity and ecosystems. They can complement these policies but not substitute them. Accelerating the implementation of a planned policy can be considered as additional on the basis of a precise implementation plan. The French doctrine also explicitly states that no stacking of offsets is allowed [whereby a single offset action services impacts by multiple projects]. 
7. The outcome of offsets measures must be of sufficient duration, and proportional to the duration of impacts. This can be achieved through the purchase of land on which to implement offsets or through long-term contracts with land owners. This could require building working relationships with local stakeholders around offset sites.

There is, as yet, little feedback on the actual implementation of the recommendations spelled out in the 2012 guidance: development projects which are following the guidance are still in their early stages, especially concerning the actual implementation of offsets. Nevertheless, experience from best practice in offset design and implementation (reviewed among others by McKenney \& Kiesecker 2009, Wissel \& Wätzold 2010, Quétier \& Lavorel 2011 and Bull et al. 2013) provides clues as to possible difficulties in ensuring that offsets effectively contribute to NNL. We discuss below how the French NNL policy addresses some of these key challenges.

\section{Critical review of the French NNL policy}

We use the French NNL policy as a running example to establish how it stands relative to some of the key challenges for achieving NNL through offsets.

\section{Scope: which residual impacts are significant enough to require offsetting?}

In France, regulatory obligations cover a wide range of biodiversity and ecosystems (Figure 2) which are generally closely intertwined through ecological processes (Regnery et al. 2013). This does not mean that offsets are required everywhere, every time. Deciding when offsets are actually required for NNL is critical (Pilgrim et al. 2013). The mitigation hierarchy clearly means that for any given plan or project, a key first step to designing offsets is to establish whether any "significant" or "non-negligible" residual impact has or is actually likely to occur after the necessary avoidance and reduction measures are taken.

Although the baseline for assessing impacts is the state of the environment when permits are sought, the significance of the residual loss of biodiversity should be analysed against the current status and trends of the affected component of biodiversity, including spatial and temporal variability (Maron et al. 2013). This assessment is currently done case-by-case, typically through best professional judgement by trained and experienced professionals hired by developers (their certification is being considered - MEDDE 2011). While some guidance is provided on how to proceed (e.g. MEDDE 2012b \& MEDDE 2013) there are no compulsory methods. The only exception concerns the Common Hamster (Cricetus cricetus L.) for which a single assessment method is accepted under Ministerial Order DEVL1231144A of August 2012. This specificity results from court action by the European Commission (Case C-383/09) arguing that France was not fulfilling its obligations towards the conservation of the species, which is listed in Annex IV of the Habitats Directive. While giving space to case-specific assessment methods is often positive, critical knowledge gaps often remain. No formal process has been put in place to establish, ahead of project per project permitting, the ecological thresholds against which to assess significance (Briggs \& Hudson 2013). This is particularly critical when considering cumulative effects and assessing impacts of planning documents.

\section{Cumulative effects: first come - first served?}

Cumulative effects result from the additive effects of several plans or projects within a region and encompass both direct (destruction, mortality, or loss of function) and indirect (displacement, reduced breeding success) effects (Kiesecker et al. 2010). Although changes in the French EIA procedures have now detailed how other plans or projects must be taken into 
consideration at the project level, the issue remains that cumulative impacts are addressed through a "first come, first served" permitting process. This sets the stage for progressively lowering the thresholds beyond which additional impacts can no longer be considered negligible (i.e. "death by a thousand cuts"). Furthermore, no recommendations have been made to ensure compatibility between the data or methods used for assessing impacts across projects. Accessing data from third party projects can also be tricky and developers are left to their own devices on this matter.

\section{Metrics: how are losses and gains measured and compared?}

Demonstrating that offsets will achieve NNL requires establishing equivalence between "losses" and "gains" through appropriate metrics. This issue has been discussed abundantly in the literature (e.g. Salzman \& Ruhl 2000, Caro et al. 2010, Quétier \& Lavorel 2011, Robertson et al. in press). Using highly specific, tailored, metrics, e.g. for "species for species" offsets, means that decomposing an impact into losses affecting a wide range of specific components of biodiversity and ecosystems will lead to the joint use of multiple metrics. This generates complexity (and additional costs) for which developers and regulators are ill-prepared, even if the conservation outcome is more tractable. Standardized methods could contribute to lowering transaction costs (Robertson 2004) but have yet to emerge. The French 2012 guidance has not recommended any methodology for assessing equivalence but grouping components into broader categories (e.g. species sharing similar habitat requirements), with their associated metrics (e.g. the characteristics of the shared habitat), could make assessing equivalence more straightforward, and ensure that wholly functional ecosystems are restored through offsets. Using such a habitat or ecosystem-based approach is akin to bundling different goals (species, habitat types, ecosystem functions or services). Of course, less specific equivalence metrics lend more flexibility to developers for finding adequate solutions to their offsetting obligations (Robertson 2004).

Establishing equivalence is where the issue of substitutability is addressed (Table 1) and through it the type sustainability that NNL policies aim to achieve (Roach \& Wade 2006, Levrel et al. 2012a). The French 2012 guidance is aiming for strong levels of sustainability through highly targeted like-for-like equivalence (e.g. species for species, at a local level, under the derogation procedures). Nevertheless, strict equivalence could be unachievable and yet development projects allowed to proceed with their impacts. In these situations, impacts on a less valuable type of biodiversity could be offset through actions in favour of a more valuable type of biodiversity. Specific metrics need to be developed for such 'trading up' or 'like for better' offsets that make explicit the relative value of different biodiversity components among those for which such trading-up is considered acceptable, e.g. as developed in the UK pilot scheme on offsets (DEFRA 2012) and as documented in Florida by Levrel et al. (2012b). The French 2012 guidance does not address this issue and provides no guidance on the potential for using offsets as an innovative financing mechanism for high priority biodiversity, or how this could be done in practice. Local permitting authorities and developers seeking permits are left to establish (and negotiate) conservation priorities on a case by case basis.

\section{Timing: when should offsets be implemented, and effective?}

Transient biodiversity losses will likely result if development and its impacts are allowed to take place before offsets are secured. Cumulatively, these could lead to bottleneck effects (Gibbons and Lindenmayer 2007, Bendor, 2009). Transient losses can be factored into the design and sizing of offsets (e.g. as under the European Environmental Liability Directive 2004/35/EC which applies to accidental damage). The most straightforward solution, however, is to require that offsets be effective before losses occur. The French 2012 Guidance 
mentions this but does not describe how it could be achieved in practice. Offset gains could be "banked", as recommended for offsetting wetland impacts in the USA (Hough \& Robertson 2009), but France has only recently launched an "experiment" into this (which we describe at the end of Section 3).

\section{Feasibility: how to achieve biodiversity gains?}

Offsets aim to provide "gains" that are at least equivalent to the "losses" caused by impacts but such gains depend on our ability to shape a population or an ecosystem in the desired direction. Offset success greatly depends on the specifics of the particular offset actions. The reliability, time-frame, and cost, of these projects for generating biodiversity gains are key issues for demonstrating the feasibility of a particular offset scheme.

The science base for designing and implementing ecological restoration, rehabilitation, or conservation actions is still young (Pullin \& Knight 2009, Suding 2011). Unfortunately, no targeted mechanism has been established to build or feed the corresponding knowledge base, e.g. through the compulsory monitoring and evaluation of offsets (for a discussion on this issue see Tischew et al. 2010). In fact, no formal reporting mechanism has been established to document the ecological performance of offsets. Nevertheless, some developers and local authorities are developing their own, in-house, mechanisms for keeping track of offset commitments.

Still, some general insight can be gained from restoration science and practice (Benayas et al. 2009, Maron et al. 2012, Moreno-Mateos et al. 2012). For instance, restoring degraded ecosystems is generally more likely to succeed, and more rapidly, than re-creating ecosystems because they are more likely to re-establish required and desired functions (e.g. Mitsch and Wilson 1996, Kozich and Halvorsen 2012, Moreno-Mateos et al. 2012). Aiming to maximize 'gains per unit area' doesn't always work, and uncertainties surround the success of offsets must be factored into their design and sizing (see Pickett et al. 2013 for an example). The same goes for the time it takes for offsets to actually achieve their target outcomes (Gibbons \& Lindenmayer 2007, Moilanen et al. 2009, BenDor 2009). In fact, focusing efforts on the underlying ecosystem properties and processes, rather than on targeted outcomes for a limited set of species or indicators, is more likely to generate long term outcomes (e.g. McGregor et al. 2011), as advocated in ecosystem-based management (and discussed in Bullock et al. 2011). This questions the usefulness of highly targeted offset requirements, and hence highly specific NNL targets.

A favourable landscape context, such as one with nearby sources of propagules or without detrimental land-uses, often plays a key role in determining success (e.g. Fagan et al. 2008, Woodcock et al. 2010, Dalang \& Hersperger 2012 - but see Hodgson et al. 2011). This means that offsets have to be located strategically, especially in relation to on-going conservation actions and protected areas, and that grouping offsets for several projects into one shared restoration project is more likely to be achieve NNL (as illustrated in Figure 3). There are risks, however, with concentrating offsets into a few locations (Moilanen et al. 2009). The 2012 guidance mentions these key elements of offset design and implementation but provides decision support on offset location.

\section{Access to land: where should offsets be located?}

Access to land is critical to generating the biodiversity "gains" that are required for achieving NNL in the context of urban development and industrial and infrastructure projects. Appropriate guidance on the location of offsets is essential to ensure that developers do not systematically reduce the cost of offsetting by targeting cheap land with no consideration for 
the effectiveness of their choices for achieving NNL. Requiring that offsets be located close to impacts doesn't automatically improve effectiveness and 'functional proximity', mentionned in the 2012 French guidance, should be better defined. The 'green and blue vein' policy that was an outcome of the Grenelle de l'Environnement consultative process provides a useful framework for this. Other options include landscape-level models of existing and potential biodiversity in relation to land-cover and land-use (e.g. Gordon et al. 2009, Bekessy et al. 2012, van Teeffelen et al. 2012). In such frameworks, biodiversity offsets can contribute to combining a per-project approach to mitigating development impacts (under the responsibility of developers) with species- or habitat-centred conservation strategies developed at varying spatial scales, as illustrated in Figure 3 and promoted by Kiesecker et al. (2010), Dreschler et al. (2011) and Underwood (2011). Mitigation banking, as practiced in some US states, is one mechanism among others for locating offsets strategically (Martin \& Brumbaugh 2013). No such mechanism has been established in France, but some local governments are developing their own, local, offset strategies.

\section{Additionnality: against what baseline are my offsets designed and assessed?}

Inserting biodiversity offsets into a broader strategic framework for nature conservation provides greater assurances that the corresponding biodiversity gains will be relevant, and that they will be located in an adequate location relative to existing protected areas or future infrastructure and urbanization plans. While this is very positive, it also raises the question of their additionnality relative to existing nature conservation policies and competing sources of funding. Demonstrating additionnality requires that public policies be realistically included in the baselines used to assess losses and gains (Maron et al. 2013). Although the French NNL policy explicitly mentions this issue, no guidance is given on how existing and planned commitments can be identified, assessed, and included in the design of offsets.

\section{Long term outcomes: conservation is forever, but what about offsets?}

Once suitable land is found, guarantees must also be given concerning funding, and protection status of offsets. The 2012 French guidance states that offsets should remain effective for as long as impacts last. Impacts that are considered irreversible, such as those resulting from built infrastructure, would therefore require that the conservation outcomes of offsets be irreversible, i.e. they should last into perpetuity. This is never the case in practice as duration is negotiated on a case-by-case basis between developers and authorities. Under most publicprivate partnerships used to finance new infrastructure in France, it is the duration of the concession that determines the duration of the offset. What happens after that is anyone's guess! Some offsets could end up in the government's remit, but this then raises the issue of additionnality.

Developers remain liable for their offsets, even if only for a designated (and variable) amount of time, yet offsetting usually involves local NGOs who are (graciously) handed over land titles and stewardship, or even the responsibility of coordinating offset implementation with third parties: e.g. paying farmers and land-owners for management that is, e.g., favourable to the targeted species. This is often done through short term contracts (akin to agrienvironmental measures under the European Common Agricultural Policy). Land purchased by developers can also be handed over to public bodies such as the Conservatoire de l'Espace Littoral et des Rivages Lacustres, a statutory land trust which offers high levels of protection from development for land it owns along sea and lake coasts, or local governments (municipal or department-level), which offer lower levels of legal protection (unless their land is put under a protected area regime). 
There is no guidance concerning the requirements that environmental authorities can impose in terms of liabilities, duration, and financial terms for these complex set-ups. As a result, the contractual regimes that are put in place are always ad-hoc, fragile, and generally offer low levels of protection and minimal financial or legal commitments. The absence of requirements does, however, leave space for innovation.

\section{Monitoring, reporting and compliance}

The EIA reform has made monitoring and reporting of avoidance, reduction and compensation measures compulsory. However, little guidance is available as to the design of monitoring (indicators etc.), their duration or frequency. Monitoring and reporting is under the responsibility of developers, but tends to be subcontracted to third parties, typically to the organisations in charge of executing offsets. No mechanisms have been set up in France to require third-party verification of offset performance.

Various models are currently being trialled to respond to the increasing demand for offsets. In 2011, the French government launched a pilot "experiment" to test models akin to "habitat banking" whereby third parties generate biodiversity gains ahead, and independently, of project permitting, and can cater for offsets of multiple projects. Only one such "bank" (with 357 ha of restored grasslands, run by a public financial institution - Chabran, \& Napoléone 2012) is currently established, but four more are being set-up as part of the experiment. Local governments are also setting up schemes to coordinate offset implementation through models akin to in-lieu fee systems. The restoration of 85 ha of wetlands around the city of Chambéry will, for example, be partly funded by developers through offsets for impacts on wetlands (Chambéry Métrople, 2012). The remaining restoration will be funded through subsidies by various public funding agencies.

Key avenues for innovation lie with location and timing of offsets through aggregated offsets, in order to streamline access to offsets for developers (while still providing the desired ecological outcome). Any solution, however, has to be negotiated by developers with permitting authorities, on a project per project basis. This leaves little room for third parties (whatever their status: private firms, NGOs or public bodies) to offer alternative solutions with stronger NNL commitments. Such commitments are not favoured by current guidance but also suffer the absence of dedicated instruments for ensuring that offsets are adequately protected, funded and monitored. There are currently no legal tools in France that are comparable to the conservation easements used in the USA to offer legal protection to land harbouring offsets, for example in the case of changes in ownership. Similarly, little consideration is given by environmental authorities to ensuring that sufficient funds will be available to manage the offset through time, especially beyond the duration for which developers remain liable (e.g. through financial assurances or trust fund mechanisms).

\section{Discussion}

The current debate on NNL and offsets in France is focused on impacts caused by development (urban expansion, infrastructure, and industrial projects, including renewable energy, extractive industries, etc.), in the context of permitting procedures. Human activities that cause losses of biodiversity but for which permits are generally not required (e.g. farming and forestry practices or fisheries) are not currently required to achieve NNL. By design, the French NNL policy should therefore be understood as limited to pressures on biodiversity arising from urbanization, infrastructure and industry. 
This NNL policy has been established very progressively since 1976 , by building on a disparate set of sectorial policies (e.g. that target protected species of fauna and flora, natural habitats, wetlands, forests, etc. - Figure 2). The preferred approach appears to have been "learning by doing" (or rather "not doing") but has culminated in an ambitious policy spelled out in the 2012 guidance (MEDDE 2012a). Strict like-for-like equivalence is sought, hinting at strong sustainability (Table 1), and this could significantly raise the stakes for appropriately accounting for biodiversity in the design and approval of development projects. In fact, the constraint of offsetting obligations and the "demand" for offset solutions are now firmly established for most plans and projects that are likely to have residual impacts after appropriate avoidance and reduction measures have been taken.

Our analysis shows, however, that the NNL policy's ambition is not immediately operational. It did not fully tackle some of the key design elements for effective implementation, in particular concerning the long term commitments to ecological performance that offsets require if they are to achieve NNL (Table 2). The French guidance does not outline the institutional arrangements that could enable effective implementation (e.g. individual offsets, habitat banking, in-lieu fees or other financial compensation schemes), or the standards and performance criteria under which these arrangements will be designed and monitored. Possible providers of offsets are not identified, and possible audit, certification and accreditation systems are not discussed. Little detail is provided on enforcement and the consequences of technical or financial failures of offsets. This is not specific to France, and such inadequacies be considered in any offset-based NNL policy.

Because these key design elements have not been clarified at the on-set, the burden of operationalizing the guidance is being shifted from the national government to regional permitting authorities and then onto individual developers and/or local governments who must design their own solutions. This results in very heterogeneous (and unpredictable) implementation across projects and regions, and considerable difficulty in establishing whether NNL will be achieved.

We identify two key areas on which progress is urgently required: strengthening the knowledge base on which offset design and implementation is built and developing adequate institutions for implementing offsets.

\section{The knowledge base to inform offset design and execution}

There is considerable scope for improving existing methods used to establish equivalence between "losses" and "gains" (Quétier \& Lavorel 2011). Although standardized metrics are not always best suited (especially for critical biodiversity and ecosystems), effective implementation could benefit from the development of metrics that are comparable across development projects, and which could be used to document "gains" obtained through conservation or restoration actions carried out by offset providers. The same metrics could be used to assess significance of impacts, across projects. This is especially important for addressing cumulative impacts, e.g. to establish thresholds beyond which local population viability is jeopardized, and to identify the most suited location and types of offset actions, e.g. in relation to conservation priorities (Figure 3). Public authorities have a key role to play in encouraging the development of such metrics, and in framing their use. They should also provide guidance on how offsets should fit into existing and planned commitments to conservation and restoration, beyond typical project per project permitting.

Demonstrating the feasibility (and time-lag) of offsets is a central requirement of the 2012 guidance. This, however, requires a stronger evidence base. It can be fed by targeted scientific research but would also gain from feed-back on past and on-going applications. The 
compulsory monitoring of offsets introduced in 2012 could provide impetus for this but it would require offset providers to follow adaptive management principles where hypotheses are made and tested on the causes of success and failure. These principles have to be built into offset design and management but it is likely that their cost cannot rest entirely on developers. Furthermore, the data produced has to be fed into a shared resource base that can inform the design, execution and long term management of offsets. Public authorities have a key role to play in building such a resource base, and the mechanisms to feed it.

\section{Institutions to deliver offsets and demonstrate $N N L$}

It does not make sense to create a new environmental policy if you do not create, at the same time, the organizations to govern it, the institutional frameworks to enforce it, and the assessment tools to evaluate the policy's efficiency (Hahn \& Richards 2013). What would make sense is to establish clear requirements for the institutional arrangements that can deliver the long term ecological outcomes expected from offsets, which themselves condition the permits granted to developers for their projects.

In spite of the ambition clearly laid out in its 2012 guidance, those involved in designing and implementing offsets in France are left to develop local solutions, with varying levels of commitment. This certainly fosters innovation but the capacity of public authorities to oversee highly variable offset arrangements over the long term, and enforce the desired ecological outcome (i.e. NNL), is questionable. This should be addressed urgently. To achieve this, major innovations are required on property rights, i.e. enabling conservation easements and transfers of liabilities to registered offset providers, and on the contractual obligations attached to offset delivery, i.e. in terms of technical and financial capacity (as discussed by Coggan et al. 2013a \& 2013b). In France as elsewhere, a dedicated set of organizations could be built around these obligations to provide higher levels of performance than is currently the case.

In conclusion, our analysis has shown that establishing a NNL policy has been a long and winding process. It has generated a new regulatory context and a "demand" for offsets. This is a positive outcome, even if there is still considerable room for progress in improving the design of offsets. Our main concern, however, is that little has been done to ensure that the demand for offsets can be satisfied. Unless appropriate institutional frameworks are built to ensure that offsets deliver on their promised ecological performance, the likely outcome will be an expansion of "paper offsets".

\section{Acknowledgements}

The ideas in this paper greatly benefited from fruitful discussions in the working group on setting guidelines for applying the mitigation hierarchy in France, chaired by the French Ministry of Environment, and discussions in the working group on no net loss, convened by the European Commission. Special thanks go to Marc Lansiart, Elen Lemaitre - Curri, Delphine Morandeau and Michel Perret (French Ministry of Environment) as well as Michel Echaubard and Serge Muller (Conseil National de Protection de la Nature). Useful comments on the manuscript were provided by Denis Couvet, Nathalie Frascaria-Lacoste, Christian Kerbiriou and Damien Marage.

We acknowledge funding by the Mission Biodiversité of the Caisse des Dépots et Consignations, the Cluster Recherche Rhône Alpes, the PIR IngECOTech "Ingénierie et equivalence", the Conseil Général de l'Isère and CEA / Agence ITER France (arrêté préfectoral $\mathrm{n}^{\circ} 200863-5$ du 3 mars 2008). The research leading to these results has received 
funding from the European Union Seventh Framework Programme (FP7/2007-2013) under grant agreement n`308393 "OPERAs".

All opinions expressed in this paper are strictly those of the authors and do not in any way represent the opinion of the above-stated working groups, the French Ministry of Environment, the European Commission, or the Conseil National de Protection de la Nature.

\section{References}

BBOP. 2012. Standard on Biodiversity Offsets. Business and Biodiversity Offsets Programme, Washington, D.C., USA.

Bekessy, S.A., White, M., Gordon, A., Moilanen, A., Mccarthy, M.A. \& Wintle, B.A. 2012. Transparent planning for biodiversity and development in the urban fringe. Landscape and Urban Planning 108, 140-149.

Benayas, J.M.R., Newton, A.C., Diaz, A. \& Bullock, J.M. 2009. Enhancement of Biodiversity and Ecosystem Services by Ecological Restoration: A Meta-Analysis. Science, 325, 5944, 1121

BenDor, T. 2009. A dynamic analysis of the wetland mitigation process and its effects on no net loss policy. Landscape and Urban Planning 89, 17-27.

Briggs S. \& Hudson M.D. 2013. Determination of significance in ecological impact assessment: past change, current practice and future improvements. Environmental Impact Assessment Review 38, 16-25.

Bull, J.W., Shuttle, K.B., Gordon A., Singh, N.J. \& Milner-Gulland, E.J. 2013. Biodiversity offsets in theory and practice. Oryx 47 (03, 369-380.

Bullock, J.M., Aronson, J., Newton, A.C., Pywell, R.F. \& Rey-Benayas, J.M. 2011. Restoration of ecosystem services and biodiversity: conflicts and opportunities. Trends in Ecology \& Evolution 26 (10), 541-549.

Caro, T.M. 2010. Conservation by proxy: Indicator, umbrella, keystone, flagship, and other surrogate species. Island Press, Washington, D.C., USA.

Chabran F. \& Napoléone C. 2012. Les conditions du développement des banques d'actif naturels en France - Analyse du régime institutionnel de la première réserve d'actifs naturels française. Développement Durable et Territoires 3(1), on-line. http://developpementdurable.revues.org/9199

Chambéry Métrople. 2012. Signature du plan d'actions en faveur des zones humides (PAFZH) de Chambéry métropole. Chambéry Métropole, Chambéry, France.

Coggan, A., Buitelaar, E., Whitten, S.M. \& Bennett, J. 2013a. Intermediaries in environmental offset markets: Actions and incentives. Land Use Policy 32, 145-154.

Coggan, A., Buitelaar, E., Bennet, J. \& Whitten, S.M. 2013b. Transferable mitigation of environmental impacts of development: two cases of offsets in Australia. Journal of Environmental Policy \& Planning 15(2), 303-322.

Conseil Constitutionnel 2012. Décision n²012-269 QPC du 27 juillet 2012 - Commentaire. Conseil Constitutionnel, Paris, France, 7 p.

Dalang, T. \& Hersperger, A.M. 2012. Trading connectivity improvement for area loss in patch-based biodiversity reserve networks, Biological Conservation 148, 1-116. 
DEFRA 2012. Biodiversity offsetting Pilots. Technical paper: the metric for the biodiversity offsetting pilot in England. Department for Environment, Food and Rural Affairs, London, UK.

Ekins, P. 2003. Identifying critical natural capital: Conclusions about critical natural capital, Ecological Economics 44 (2-3), 277-292.

European Commission. 2007a. Guidance document on the strict protection of animal species of Community interest under the Habitats Directive 92/43/EEC. European Commission, Brussels, Belgium

European Commission. 2007b. Guidance document on Article 6(4) of the "Habitats Directive" 92/43/EEC. European Commission, Brussels, Belgium

European Commission. 2011. Our life insurance, our natural capital: an EU biodiversity strategy to 2020. 3.5.2011. COM(2011) 244. European Commission, Brussels, Belgium

Fagan, K. C., Pywell, R. F., Bullock, J. M. and Marrs, R. H. 2008. Do restored calcareous grasslands on former arable fields resemble ancient targets? The effect of time, methods and environment on outcomes. Journal of Applied Ecology, 45: 1293-1303.

Gibbons, P. \& Lindenmayer, D.B., 2007. Offsets for land clearing: no net loss or the tail wagging the dog? Environmental Management and Restoration 8, 26-31.

Gordon, A., Simondson, D., White, M., Moilanen, A. \& Bekessy, S.A. 2009. Integrating conservation planning and landuse planning in urban landscapes. Landscape and Urban Planning 91(4), 183-194.

Hahn, R. \& Richards, K. 2013. Understanding the effectiveness of environmental offset policies. Journal of Regulatory Economics 44, 103-119.

Hodgson, J. A., Moilanen, A., Wintle, B. A. \& Thomas, C. D. 2011. Habitat area, quality and connectivity: striking the balance for efficient conservation. Journal of Applied Ecology 48, $148-152$.

Hough, P. \& Robertson, M. 2009. Mitigation under Section 404 of the Clean Water Act: where it comes from, what it means. Wetland Ecology and Management 17, 15-33.

Jiricka, A. \& Pröbstl, U. 2009. One common way - The strategic and methodological influence on environmental planning across Europe. Environmental Impact Assessment Review 29, 379-389.

Kiesecker, J.M., H. Copeland, A. Pocewicz, and B. McKenney, 2010. Development by design: blending landscape level planning with the mitigation hierarchy. Frontiers in Ecology and the Environment 8, 261-266.

Kozich, A.T., Halvorsen, K.E. 2012. Compliance with Wetland Mitigation Standards in the Upper Peninsula of Michigan, USA. Environmental Management 50, 97-105.

Ledoux, L., Crooks, S., Jordan, A. \& Turner, R.K. 2000. Implementing EU biodiversity policy: UK experiences. Land Use Policy 17, 257-268.

Levrel H., Hay J., Bas A., Gastineau P. \& Pioch S. 2012a. Coût d'opportunité versus coût du maintien des potentialités écologiques : deux indicateurs économiques pour mesurer les coûts de l'érosion de la biodiversité. Natures, Sciences, Sociétés 20, 16-29.

Levrel, H., Pioch, S. \& Spieler, R. 2012b. Compensatory mitigation in marine ecosystems: which indicators for assessing the "no net loss" goal of ecosystem services and ecological functions? Marine Policy 36(6), 1202-1210. 
MAAF. 2013. Circulaire DGPAAT/SDFB/C2013-3060. Du 28 mai 2013, Ministère de l'Agriculture, de l'Agroalimentaire et de la forêt, Paris, France.

Maron, M., Hobbs, R.J., Moilanen, A., Matthews, J.W., Christie, K., Gardner, T.A., Keith, D.A., Lindenmayer, D.B. \& McAlpine, C.A. 2012. Faustian bargains? Restoration realities in the context of bodiversity offset policies. Biological Conservation 155, 141-148.

Maron, M., Rhodes, J.R. \& Gibbons, P. 2013. Calculating the benefit of conservation actions. Conservation Letters 6(5), 359-367.

Martin, S. \& Brumbaugh, R. 2013. Defining service areas for wetland mitigation: an overview. Wetlands Newsletter 35(2), 9.

McGillivray, D. 2012. Compensating biodiversity loss: the EU Commission's approach to compensation under Article 6 of the Habitats Directive. Journal of Environmental Law 24 (3), 417-450.

McGregor, A., Coffey, B., Deutsch, C., Wescott, G. \& Robinson, J. 2011. What are the policy priorities for sustaining ecological processes? A case study from Victoria, Australia. Ecological Management \& Restoration 12, 194-199.

McKenney, B.A. \& Kiesecker, J.M. 2009. Policy Development for Biodiversity Offsets: A Review of Offset Frameworks. Environmental Management, 45(1), 165-176.

MEDDE. 2011. Compétences et professionnalisation des bureaux d'études au regard de la qualité des études d'impact (évaluations environnementales). Rapport n ${ }^{\circ} 007411-01$ Conseil Général de l'Environnement et du Développement Durable, MEDDE, Paris, France.

MEDDE. 2012a. Doctrine relative à la séquence éviter, réduire et compenser les impacts sur le milieu naturel. Ministère de l'Écologie, du Développement Durable et de l'Energie, Paris, France.

MEDDE. 2012b. Guide «Espèces protégées, aménagements et infrastructures ». Ministère de l'Écologie, du Développement Durable et de l'Energie, Paris, France.

MEDDE. 2013. Lignes directrices nationales sur la séquence éviter, réduire et compenser les impacts sur les milieux naturels. Ministère de l'Écologie, du Développement Durable et de l'Energie, Paris, France.

Millennium Ecosystem Assessment. 2005. Ecosystems and HumanWell-being: Synthesis. Island Press, Washington, D.C., USA.

Mitsch, W.J., Wilson, R.F. 1996. Improving the success of wetland creation and restoration with know-how, time, and self-design. Ecological Applications 6, 77-83.

Moilanen A., van Teeffelen A.J.A., Ben-Haim Y., Ferrier S. 2009. How Much Compensation is Enough? A Framework for Incorporating Uncertainty and Time Discounting When Calculating Offset Ratios for Impacted Habitat. Restoration Ecology 17, 470-478

Morandeau D. \& Vilaysack D. 2012. La compensation des atteintes à la biodiversité à l'étranger - Etude de parangonnage. Etudes et Documents 68. Conseil Général de l'Environnement et du Développement Durable, MEDDE, Paris, France.

Moreno-Mateos, D., Power, M.E., Comín, F.A. \& Yockteng, R. 2012. Structural and Functional Loss in Restored Wetland Ecosystems. PLoS Biology 10(1): e1001247.

Pearce D.W. \& Atkinson G.D. 1993. Capital theory and the measurement of sustainable development: An indicator of "weak" sustainability. Ecological Economics 8 (2), 103-108. 
Pickett, E.J., Stockwell, M.P., Bower D.S., Garnham, J.I., Pollard, C.J., Clulow, J. \& Mahony, M.J. 2013. Achieving no net loss in habitat offset of a threatened frog required high offset ratio and intensive monitoring. Biological Conservation 157, 156-162.

Pilgrim J.D., Brownlie, S., Ekstrom J.M.M., Gardner T.A., von Hase, A., ten Kate, K., Savy, C.E., Stephens, R.T.T., Temple H.J., Treweek, J., Ussher G.T. \& Ward, G., 2013. A process for assessing the offsetability of biodiversity impacts, Conservation Letters, in press.

Pullin, A. S. \& T. M. Knight. 2009. Doing more good than harm: building an evidence-base for conservation and environmental management. Biological Conservation 142, 931-934.

Quétier, F. \& Lavorel, S. 2011. Assessing ecological equivalence in biodiversity offset schemes: Key issues and solutions. Biological Conservation 144(12), 2991-2999

Regnery, B., Couvet, D. \& Kerbiriou, C. 2013. Offset measures and development projects: the conservation of protected species under the EU Birds and Habitats Directives. Conservation Biology, in press.

Roach, B. \& Wade, W.W. 2006. Policy evaluation of natural resource injuries using habitat equivalency analysis. Ecological Economics 58(2), 421-433.

Robertson, M., BenDor, T., Lave, R., Riggsbee, A., Ruhl, J.B., and Doyle M. in press. Stacking ecosystem services. Frontiers in Ecology and Environment, in press.

Robertson, M.M. 2004. The neoliberalization of ecosystem services: wetland mitigation banking and problems in environmental governance. Geoforum 35(3), 361-373.

Salzman, J. \& Ruhl, J.B. 2000. Currencies and the Commodification Environmental Law. Stanford Law Review 53, 607-694.

Secrétariat technique du bassin Loire-Bretagne, 2010. Fiche d'aide à la lecture du SDAGE Loire - Bretagne. Application de la disposition 8B-2 du SDAGE Loire-Bretagne sur les zones humides (fiche ${ }^{\circ} 2$ ). DREAL Centre, Orléans, France.

Suding, K.N. 2011. Toward an era of restoration in ecology: successes, failures, and opportunities ahead. Annual Review of Ecology, Evolution, and Systematics 42, 465-487.

Tischew, S., Baasch, A., Conrad, M.K. \& Kirmer, A. 2010. Evaluation restoration success of frequently implemented compensation measures: Results and demands for control procedures. Restoration ecology 18(4), 467-480.

Underwood, J.G., 2011. Combining Landscape-Level Conservation Planning and Biodiversity Offset Programs: A Case Study. Environmental Management 47, 121-129.

van Teeffelen, A.J.A., Vos, C.C. \& Opdam, P. 2012. Species in a dynamic world: Consequences of habitat network dynamics on conservation planning. Biological Conservation 153, 239-253.

Wissel, S. \& Wätzold, F., 2010. A Conceptual Analysis of the Application of Tradable Permits to Biodiversity Conservation. Conservation Biology, 24(2), 404-411.

Woodcock, B. A., Vogiatzakis, I. N., Westbury, D. B., Lawson, C. S., Edwards, A. R., Brook, A. J., Harris, S. J., Lock, K. A., Maczey, N., Masters, G., Brown, V. K. \& Mortimer, S. R. 2010. The role of management and landscape context in the restoration of grassland phytophagous beetles. Journal of Applied Ecology 47, 366-376. 


\section{TABLES}

\begin{tabular}{|l|l|l|l|}
\hline \multicolumn{1}{|c|}{ Description } & \multicolumn{1}{|c|}{ Substitution issue } & \multicolumn{1}{|c|}{ Level of sustainability } \\
\hline $\mathbf{1}$ & Natural capital is destroyed & $\begin{array}{l}\text { Net loss of biodiversity and } \\
\text { wealth / well-being }\end{array}$ & Not sustainable \\
\hline $\mathbf{2}$ & $\begin{array}{l}\text { Natural capital is replaced by physical } \\
\text { or human capital with maintenance of } \\
\text { wealth }\end{array}$ & $\begin{array}{l}\text { No net loss of wealth / well- } \\
\text { being }\end{array}$ & $\begin{array}{l}\text { Weak sustainability } \\
\text { (Pearce and Atkinson 1993) }\end{array}$ \\
\hline $\mathbf{3}$ & $\begin{array}{l}\text { Natural capital is replaced by other } \\
\text { natural capital delivering different } \\
\text { ecosystem services }\end{array}$ & $\begin{array}{l}\text { No net loss of natural } \\
\text { capital }\end{array}$ & $\begin{array}{l}\text { Intermediate sustainability } \\
\text { (Ekins 2003) }\end{array}$ \\
\hline $\mathbf{4}$ & $\begin{array}{l}\text { Natural capital is replaced by the same } \\
\text { natural capital delivering the same } \\
\text { type of ecosystem services }\end{array}$ & $\begin{array}{l}\text { No net loss of ecosystem } \\
\text { cultural, regulation, support, } \\
\text { or provisioning services }\end{array}$ & $\begin{array}{l}\text { Strong sustainability } \\
\text { (Millennium Ecosystem } \\
\text { Assessment 2005) }\end{array}$ \\
\hline $\mathbf{5}$ & $\begin{array}{l}\text { Natural capital is replaced by the same } \\
\text { natural capital delivering identical } \\
\text { ecosystem services }\end{array}$ & $\begin{array}{l}\text { No net loss of specific } \\
\text { ecosystem services }\end{array}$ & $\begin{array}{l}\text { Strong sustainability } \\
\text { (Roach and Wade 2006) }\end{array}$ \\
\hline $\mathbf{6}$ & $\begin{array}{l}\text { Natural capital is not replaceable } \\
\text { No loss of biodiversity }\end{array}$ & $\begin{array}{l}\text { Not sustainable } \\
\text { (no development) }\end{array}$ \\
\hline
\end{tabular}

Table 1: Different levels of sustainability (third column) imply different types of ecological equivalencies for substituting impact losses with offset gains (second column). No net loss as defined in BBOP (2012) and in the French Government's 2012 guidance on the mitigation hierarchy is consistent with strong sustainability (situation 5). 


\begin{tabular}{|c|c|c|}
\hline Key design element & French NNL policy (2012) & Implementation gaps \\
\hline $\begin{array}{l}\text { Scope: how is significance } \\
\text { established? }\end{array}$ & $\begin{array}{l}\text { If a project is permitted in spite of significant residual } \\
\text { impacts then offsets can be used to achieve NNL (EIA } \\
\text { Reform) }\end{array}$ & \multirow{3}{*}{$\begin{array}{l}\text { No methods have been developed to assess significance across } \\
\text { projects (e.g. thresholds); } \\
\text { No methods have been developed to measure losses and gains in } \\
\text { ways that are comparable across projects, and comparable with } \\
\text { third party conservation or restoration actions; }\end{array}$} \\
\hline $\begin{array}{l}\text { How are cumulative impacts } \\
\text { addressed? }\end{array}$ & $\begin{array}{l}\text { In applying the mitigation hierarchy, developers must } \\
\text { take into account all other known plans and projects } \\
\text { (EIA reform) }\end{array}$ & \\
\hline \multirow{2}{*}{$\begin{array}{l}\text { Metrics: how are losses } \\
\text { (impacts) and gains (offsets) } \\
\text { compared? }\end{array}$} & \multirow{2}{*}{$\begin{array}{l}\text { Offsets must aim to generate gains which are at least } \\
\text { equivalent to losses, but how this is measured is } \\
\text { context dependent (1) }\end{array}$} & \\
\hline & & No mechanisms have been put in place for trading-up; \\
\hline $\begin{array}{l}\text { Technical feasibility of } \\
\text { offsets }\end{array}$ & $\begin{array}{l}\text { Offsets must be feasible, technically as well as } \\
\text { financially and socially (2), and performance-based (5) }\end{array}$ & $\begin{array}{l}\text { No mechanisms have been put in place to learn from the } \\
\text { performance of past offsets; }\end{array}$ \\
\hline $\begin{array}{l}\text { Additionnality: what is the } \\
\text { baseline for offset gains? }\end{array}$ & $\begin{array}{l}\text { Offsets must be additional to existing or planned } \\
\text { public policy targets (6) }\end{array}$ & \multirow{2}{*}{$\begin{array}{l}\text { No mechanism has been put in place to provide information on } \\
\text { existing conservation and restoration commitments that can } \\
\text { inform offset design and implementation; } \\
\text { Permitting authorities are not involved in setting conservation } \\
\text { priorities / strategies; }\end{array}$} \\
\hline $\begin{array}{l}\text { Offset location and access to } \\
\text { land }\end{array}$ & $\begin{array}{l}\text { Offsets are implemented in priority on or in } \\
\text { (functional) proximity to the damaged site ( } 3 \text { ) }\end{array}$ & \\
\hline $\begin{array}{l}\text { Duration: how long are } \\
\text { developers liable for their } \\
\text { impacts? }\end{array}$ & $\begin{array}{l}\text { Offsets must be timely (4) } \\
\text { Offsets must be of sufficient duration, proportional to } \\
\text { impacts (7) }\end{array}$ & \multirow{2}{*}{$\begin{array}{l}\text { No procedure clarifies how to cater for offsets that are effective } \\
\text { after impacts occur; } \\
\text { No minimum commitments have been set for permanent impacts; } \\
\text { No legal protection is required for land harbouring offsets; } \\
\text { No requirements (legal or financial) are specified to guarantee } \\
\text { long-term outcomes }\end{array}$} \\
\hline How are offsets funded? & $\begin{array}{l}\text { The costs of offset measures must be estimated } \\
\text { (EIA Reform) }\end{array}$ & \\
\hline
\end{tabular}

Table 2: Key design elements for an offset policy aimed at achieving NNL of biodiversity, and implementation gaps for the 2012 French policy of 2012 as spelled out in MEDDE (2012a) and MEDDE (2013), following the reform of EIA. Numbers in parenthesis refer to key design elements in the MEDDE (2012a) as numbered in Section 2 of this paper. 


\section{FIGURES}

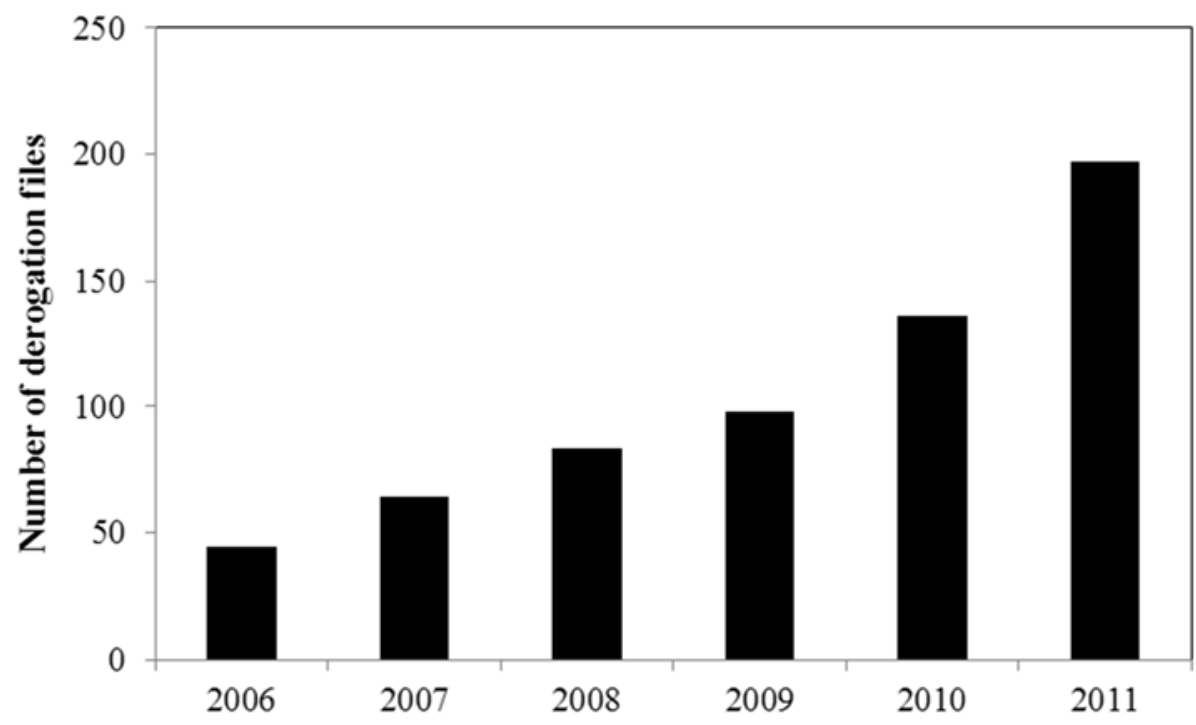

Figure 1: Number of derogation requests filed with the French Ministry of Ecology between 2006 and 2011 (from data provided by the French Ministry of Ecology, 2012) 


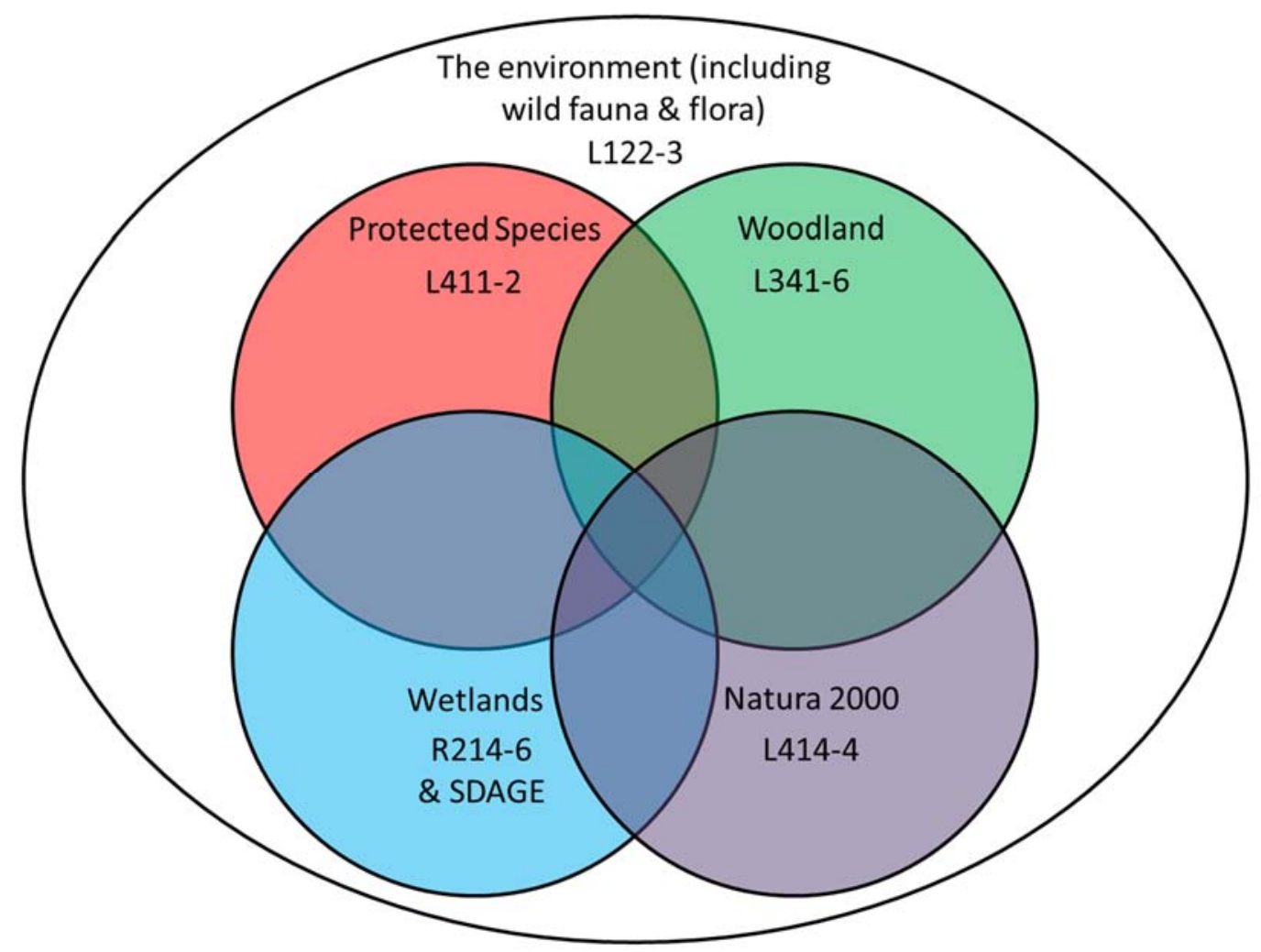

Figure 2: Several permitting procedures refer to the mitigation hierarchy. EIA applies across the board, and provide a context in which specific issues are dealt with. All these procedures are covered in the 2012 guidance which sets NNL as the expected outcome of the application of the hierarchy. Coding refers to articles in the Environment Code except for woodland which is covered by the Forestry Code. SDAGE refers to river basin management plans. The Environment and Forestry Codes, as well as the SDAGE, are legally binding. 


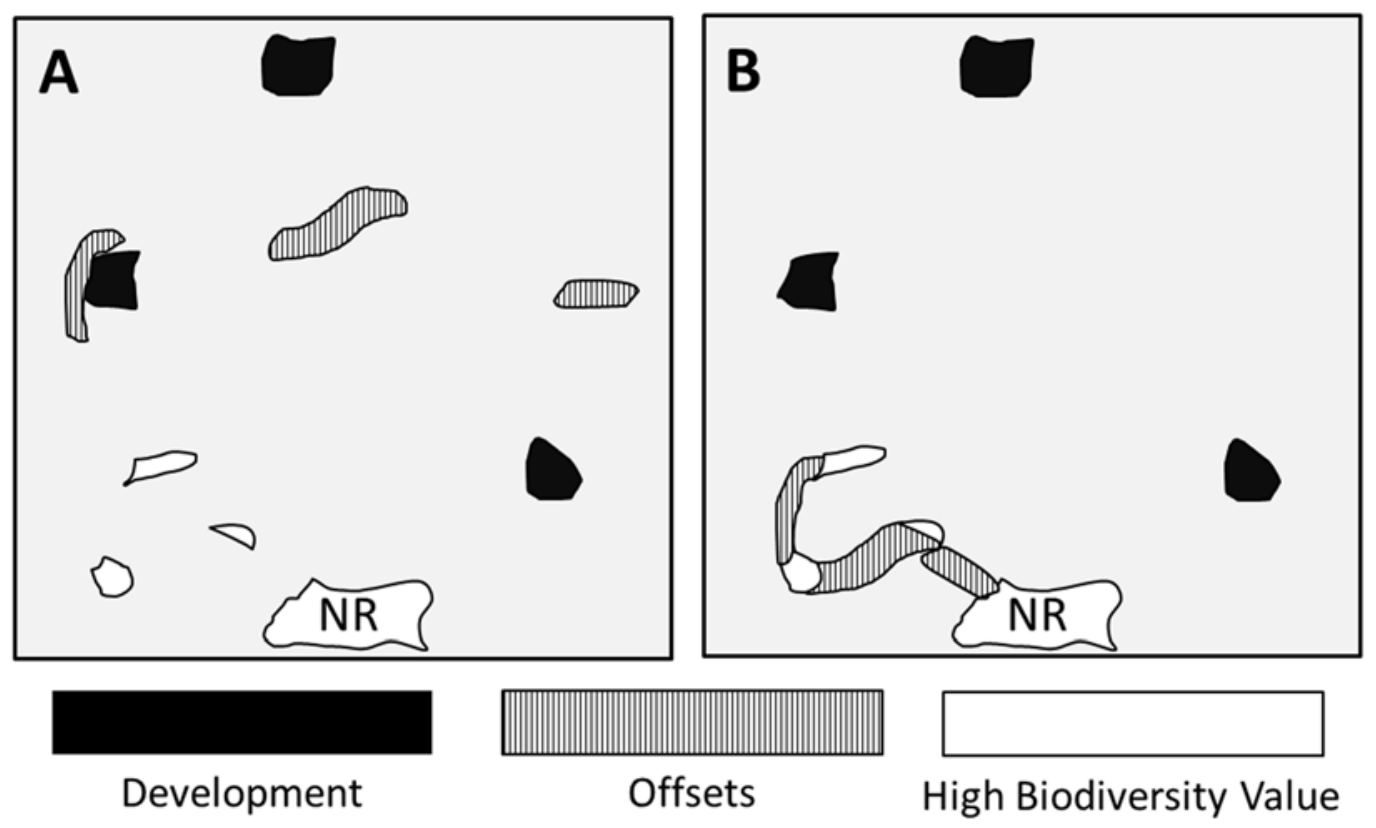

Figure 3: Illustrative maps of the currently dominant reactive, project by project, approach (A), and the proactive approach (B), where offsets are designed to contribute to nature conservation goals. The latter is needed to ensure that new offsetting requirements generate long term positive outcomes for nature conservation. NR, in the white patch, stands for 'nature reserve' and illustrates the location of a pre-existing protected area. Black patches indicate development projects while hatched patches represent the location of offset actions. 